\title{
A Cointegration Analysis on Trade Behaviour in Selected ASEAN Countries Using Dynamic Ols and Johansen Maximum Likelihood Approaches
}

\author{
NOR' AZNIN ABU BAKAR \\ Faculty of Economics \\ Universiti Utara Malaysia
}

\begin{abstract}
This paper aims to analyse the trade behaviour of four selected ASEAN countries (based on their export/import products) by using a co-integration analysis. The demand for exports and imports are estimated for the period before the currency crisis erupted (1963-1995), using the dynamic OLS (DOLS) method. The Johansen Maximum Likelihood (JML) approach is also employed to compare the results obtained. Results show that foreign income has a significant impact on export demand, suggesting that foreign disturbance in the form of economic activities is likely to be transmitted to these countries. The Marshall Lerner conditions are easily met for the case of Malaysia and Thailand (DOLS and JML). For Indonesia and the Philippines, the sum of the price elasticities of exports and imports demands are less than unity, this can be explained by the J-curve, in which the currency depreciation will first worsen the trade balance before it improves and it takes time to affect the trade balance.
\end{abstract}

\begin{abstract}
ABSTRAK
Kertas kerja ini bertujuan untuk menganalisa gelagat perdagangan bagi empat negara ASEAN terpilih (berdasarkan kepada barangan eksport/import). Permintaan eksport dan import dianggarkan untuk jangka masa 1963-1995 iaitu sebelum berlakunya krisis mata wang. Kaedah Johansen Maximum Likelihood juga digunakan untuk membandingkan keputusan yang diperolehi. Hasil kajian menunjukkan bahawa pendapatan asing mempunyai pengaruh yang signifikan ke atas permintaan eksport, mencadangkan kejutan luar dalam bentuk aktiviti ekonomi dipindahkan ke negara-negara tersebut. Keadaan Marshall-Lerner dapat dipenuhi dengan mudah untuk kes negara Malaysia dan Thailand (kaedah DOLS dan JML). Untuk kes Indonesia dan Filipina, jumlah keanjalan harga eksport dan import adalah lebih kecil dari satu. Ini dapat dijelaskan dengan keluk J, di mana penurunan nilai mata wang akan memburukkan lagi imbangan perdagangan sebelum ianya pulih dan ini akan mengambil masa untuk mempengaruhi imbangan perdagangan.
\end{abstract}

\section{INTRODUCTION}

The literature has quite extensively dealt with the estimations of the price and income elasticities of exports and imports demand. The models mostly use a simple OLS method to estimate the price and income elastic ties of exports and imports demand. The problem with this time series analysis is that we cannot draw general conclusions from the results of a particular time series analysis as the estimated parameters in the static OLS are subject to bias in small samples since the lagged terms are ignored (see Banerjee, A., Galbraith, J. W., \& Hendry, D. (1993)). One way 
to tackle this problem is by using the dynamic OLS method in which lagged and leading values of the first differences of the I (1) variables are included.

The Johansen Maximum Likelihood approach can also be used as it provides direct estimates of the cointegrating vectors and allows testing the number of cointegrating vectors. However, in practice, the Johansen approach also has a few disadvantages. First, if the sample size is small, the estimates obtained for cointegrating vector $b$ may not be well determined. Second, if the cointegrating vector is not a unique one, there will be an identification problem and it may be difficult to disentangle economically meaningful cointegrating vectors. As a consequence, a strategy is to use both these approaches and compare the results.

The responsiveness of trade flows to relative price changes is the main concern in formulating an exchange rate policy to correct the trade imbalance. If the sum of export and import demand is greater than unity, it indicates that a depreciation or devaluation will have a favourable effects on the trade balance as it satisfies the Marshall-Lerner condition. However, exchange rate policy is always accompanied by other macroeconomic policies that is, fiscal or monetary policies, as it is difficult to measure the effects of one policy without controlling for the others (see Tang, 2003). Therefore, the need to combine the effects of all the policies on trade balance are necessary. In some situations, trade balance worsens before it improves in response to depreciation; this is known as the $\mathbf{J}$ curve effect which due to the low price elasticity of demand for exports and imports in the immediate aftermath of an exchange rate change.

The purpose of this paper is to estimate the price and income elasticities of the four selected ASEAN countries' demand for exports and imports. Countries that are selected are based on characteristics of their export/import products. This study can be justified as follows:

i) It differs from most earlier studies that is, Bond (1985); Cline (1984); Goldstein
\& Khan (1982); Marquez of McNeilly (1988); Mustacelli (1994); Muscatelli, V. A.; Stevensen, A. A., \& Montagna, C. (1995a). These studies used static long run regressions in which the estimated parameters in the static long run OLS are subject to bias in small samples since lagged terms are ignored. This study uses a dynamic OLS to avoid this problem. Estimates taken from the conditional error-correction model are equivalent to full-information maximum likelihood estimates and therefore asymptotically normal, allowing standard inference. On the contrary, for the static regression case, the $t$ ratios have non-standard distributions even asymptotically (see Baffes, J., Elbadawi, I. A., \& O’ Connell, S. A., 1999).

ii) By adopting the cointegration method, the problem of spurious regression is avoided as variables involved in both export and import demands are non-stationary in their levels. The maximum likelihood approach is also employed to confirm results obtained from the dynamic OLS method. However, the Johansen procedure has serious limitations where it deteriorates dramatically in small samples, generating estimates with 'fat tails' (frequent outliers). Therefore results from the dynamic OLS method will be the main focus.

iii) The findings of this study provide empirical evidence that suggests that the exchange rate policy (i.e. Malaysia and Thailand) is effective to correct the trade balance deficit as the Marshall-Lerner condition is met.

\section{LITERATURE REVIEW}

The issue of price and income elasticities has been received much attention recently. Several methods have been used to estimate price and income elasticities of export and import demand. Studies 
done by Bond (1985), Cline (1984), Goldstein \& Khan (1982), Muscatelli (1994, 1995a), Marquez and McNeilly (1988), and O'Neill and Ross (1991) have supported the conventional view, which states that the price elasticities of demand for newly industrialised countries' (NICs) exports are small. However, the world income elasticity of demand for the NIC's exports is significant and, high. Conversely, others such as Riedel (1984; 1988; 1989), Athukorala and Riedel (1996), have criticised the conventional view, and have found that income elasticities are insignificant and the price elasticities of export demand are infinite.

Argument regarding the size of elasticities of export is the issue of normalisation. As argued by Riedel, (1989) by using the conventional approach for which export volumes are modelled as a demand equation, that depends on the domestic price relative to world price, and on world income, the price elasticities of demand tend to be low and the income elasticities of demand tend to be very high. Therefore, it is argued that the export demand function should be normalised for price rather than for quantity. Mustacelli (1994) used the Phillips-Hansen method to test Riedel's data, and found that the price elasticity of demand is actually low and income elasticities are high. Also, according to them, by using a more dynamic specification model of demand and supply, apparently the normalisation paradox disappears.

For the Malaysian case, a study done by Tang (2003) found that exports and imports of Malaysia are cointegrated. Thus macroeconomic policies are effective to bring export and import into long run equilibrium. A study done by Mohamad and Tang (2000), examines the long run relationship between aggregate imports and expenditure components of five ASEAN countries using the Johansen multivariate cointegration analysis. By using disaggregating demand variable in its components avoids the possibility of aggregate bias. Their findings showed that in the case of Malaysia, the import demand is cointegrated with its determinants and import demand is elastic with respect to relative prices. The Marshall Lerner condition is met, suggesting that devaluation is effective in correcting balance of payments disequilibrium.

As stated above, the issue of the aggregation level needs to be taken into account. Aggregation across different commodity groups, or different countries, must be well determined. Different groups of commodity can be aggregated only if the pattern of their export is comparable. Therefore in this study, ASEAN countries that are chosen are those with similar trade characteristics and trade directions.

\section{METHOD OF ESTIMATION}

Theoretical Specification of the Export and Import Functions

The world demand for exports and imports from ASEAN are specified in log linear forms as follows:

$$
\begin{aligned}
\log \mathrm{Q}_{\mathrm{xt}}{ }^{\mathrm{d}}= & \mathrm{a}_{0}+\mathrm{a}_{1} \log (\mathrm{Px} / \mathrm{Pw})_{\mathrm{t}}+\mathrm{a}_{2} \log \mathrm{Yw}_{\mathrm{t}}+ \\
& \mathrm{a}_{3} \log \mathrm{Gci}_{\mathrm{t}}+\mathrm{ux}_{\mathrm{t}} \\
& \mathrm{a}_{1}<0, \mathrm{a}_{2}>0, \mathrm{a}_{3}>0
\end{aligned}
$$

$\log \mathrm{Q}_{\mathrm{mt}}{ }^{\mathrm{d}}=\mathrm{b}_{0}+\mathrm{b}_{1} \log (\mathrm{Pm} / \mathrm{GP})_{\mathrm{t}}+\mathrm{b}_{2} \log \mathrm{Yb}_{\mathrm{t}}+$

$\mathrm{vm}_{\mathrm{t}}$

$$
\mathrm{b}_{1}<0, \mathrm{~b}_{2}>0
$$

Where $\mathrm{u}_{\mathrm{x}}, \mathrm{v}_{\mathrm{m}}$, are the error terms, $\mathrm{a}_{0}$ and $\mathrm{b}_{0}$ are the constant terms and:

$$
\begin{array}{ll}
\mathrm{Q}_{\mathrm{x}} & =\text { Export of goods } \\
\mathrm{Px} & =\text { Price of exports } \\
\mathrm{Pw} & =\text { Price of world exports } \\
\mathrm{Yw} & =\text { Scale variable } \\
\mathrm{Gci} & =\text { Export composition index } \\
\mathrm{Q}_{\mathrm{m}} & =\text { Import of goods } \\
\mathrm{Pm} & =\text { Price of home country imports } \\
\mathrm{GP} & =\text { Domestic price level } \\
\mathrm{Yb} . & =\text { Real income of home country }
\end{array}
$$

The model which is referred to as the 'equilibrium' model assumes the simplifying assumption that there are no lags in the system so that the adjustment of export and import quantities and prices to their respective equilibrium val- 
ues is instantaneous. The commonly used log linear functional form is employed instead of the linear one as it implies that the elasticities are constant.

The demand for exports (equation 1) is dependant upon the relative price of exports with respect to the world price $(\mathrm{Px} / \mathrm{Pw})$, the scale variable (Yw) which captures world demand conditions and the export composition index (Gci). The price is assumed to be homogenous in the long run so that demand depends only on relative prices and the scale variable. The choice of the scale variable may vary; some authors use (trade weighted) world income as a scale variable [Khan (1974); Goldstein \& Khan (1978); Aspe \& Giavazzi (1982); Marquez \& McNeilly (1988)] while others, for example, Muscatelli et al. (1995), use trade weighted imports of the country's export destination as a scale variable. In this study, world income is used as a scale variable. The coefficients of $a_{1}$ and $a_{2}$ are the price and income elasticities of foreign demand for home country exports and are expected to be negative and positive respectively. The export composition index is included in the export demand equation, as the commodity type effects are implicitly captured by the income and price effects if they are not included in the equation. The coefficient $\mathrm{a}_{3}$ is expected to be positive.

The demand for imports (equation 2) is dependant upon the relative price of imports with respect to the general price level (Pm/GP), and the real income of the home country (Yb). Coefficients $b_{1}$ and $b_{2}$ are expected to be negative and positive respectively.

The study uses annual data for the period of 1963-1995, specifically before the occurrence of the financial crisis. The description and the computations of variables (i.e. $\mathrm{Qx}, \mathrm{Qm}, \mathrm{Pw}$, Yw, and Gci) are given in the Appendix.

\section{INTEGRATION AND COINTEGRATION TESTS}

The Dickey-Fuller (DF) and an Augmented Dickey-Fuller (ADF) tests are used in this study to test for integration levels. These are both $t$ tests and rely on rejecting the hypothesis that the series is a random walk in favour of stationarity. By using the ADF and DF tests, the data is tested to see whether all variables are non-stationary. The DF/ADF test for the unit roots for both export and import equations for the ASEAN countries are shown in Table 1 and 2.

The Engle-Granger is widely used to estimate the long-run regression. However, the estimated parameters in the static long run OLS are subject to bias in small samples since lagged terms are ignored (see Banerjee, A., Galbraith, J. W., \& Hendry, D. (1993)). One way to correct this problem is by including dynamic components (i.e. differences and lagged) to the cointegration (Cuthbertson, K., Hall, S. G., \& Taylor, M. P. (1992).

By applying the dynamic OLS (DOLS), the potential of simultaneity bias and small sample bias among regressors is tackled that is, the inclusion of lagged and leading values of the first differences of the I (1) variables (see Phillips \& Loretan (1991), and Saikkonen (1991)). There is trade-off involved with lag length choice in the general time series regression model; using too few lags can decreases forecast accuracy because valuable information is lost, but adding lags increases estimation uncertainty. The choice of lags must balance the benefit of using additional information against the cost of estimating the additional coefficients.

One way to determine the number of lags to include is to use the F-statistic to test joint hypotheses that set of coefficients equal zero. Information criteria, that is, the BIC and AIC can be used to estimate the number of lags and variables in the time series. The model with the lowest value of the AIC (or BIC) is the preferred model. The export demand and import demand equations are estimated to include up to $\mathrm{j}= \pm 3$ leads and lags. Insignificant leads and lags will be dropped. The robust standard errors facilitate valid inferences to be made upon the coefficients of the variables entering as regressors in levels. Based on the dynamic OLS method, the long run export demand and import demand equations are as follows; 
Long-run export demand

$\mathrm{Z}=(\mathrm{a} 0, \mathrm{a} 1, \mathrm{a} 2, \mathrm{a} 3), \mathrm{X}=[1,(\mathrm{px} / \mathrm{pw}),(\mathrm{Yw}),(\mathrm{Gci})]$

$$
\begin{aligned}
Q x_{t}{ }_{t}= & z^{\prime} x_{t}+\sum_{j=-m}^{j=m} \alpha_{j} \Delta(p x / p w)_{t-j}+\sum_{j=-n}^{j=n} \beta_{j} \Delta Y w_{t-j}+ \\
& \sum_{j=-p}^{j=p} \lambda_{j} \Delta G c i_{t-j}+u x_{t}
\end{aligned}
$$

Long-run import demand

$\mathrm{Z}=(\mathrm{b} 0, \mathrm{~b} 1, \mathrm{~b} 2),, \mathrm{X}=[1,(\mathrm{pm} / \mathrm{gp}),(\mathrm{Yb})]$

$$
\begin{aligned}
Q m_{t}{ }_{t}= & z^{\prime} x_{t}+\sum_{j=-j}^{j=j} \lambda_{j} \Delta(p m / g p)_{t-j}+\sum_{j=-k}^{j=k} \eta_{j} \Delta Y b_{t-j}+ \\
& v m_{t}
\end{aligned}
$$

\begin{tabular}{|c|c|c|c|c|}
\hline \multirow{2}{*}{$\begin{array}{l}\text { Variables } \\
\text { Country }\end{array}$} & \multicolumn{2}{|c|}{ Levels } & \multicolumn{2}{|c|}{$1^{\text {st }}$ Differences } \\
\hline & DF & ADF(1) & DF & $\operatorname{ADF}(1)$ \\
\hline \multicolumn{5}{|l|}{ Malaysia } \\
\hline $\mathbf{Q}_{\mathrm{x}}{ }^{\mathrm{d}}$ & -1.4475 & -1.3313 & -5.3404 & -4.6957 \\
\hline $\mathbf{P x} / \mathbf{P w}$ & -1.8852 & -2.3029 & -4.5316 & -4.9740 \\
\hline Yw & -3.0719 & -3.1144 & -6.1905 & -4.9352 \\
\hline Gci & -2.2639 & -1.9793 & -6.2593 & -8.5296 \\
\hline \multicolumn{5}{|l|}{ Indonesia } \\
\hline$Q_{x}{ }^{d}$ & -0.7810 & -3.2414 & -4.4122 & -3.4693 \\
\hline $\mathbf{P x} / \mathbf{P w}$ & -0.8934 & -1.3512 & -3.7388 & -2.7769 \\
\hline Yw & -1.4669 & -2.1276 & -3.8660 & -2.8568 \\
\hline Gci & -3.0363 & -3.2699 & -7.3673 & -7.3029 \\
\hline \multicolumn{5}{|l|}{ Thailand } \\
\hline $\mathbf{Q}_{\mathrm{x}}{ }^{\mathrm{d}}$ & -1.7780 & -1.7399 & -5.1106 & -3.5113 \\
\hline $\mathbf{P x} / \mathbf{P w}$ & -1.6544 & -1.9116 & -5.1296 & -5.3150 \\
\hline Yw & -3.2107 & -2.1688 & -6.7846 & -3.5157 \\
\hline Gci & -2.8161 & -3.0014 & -4.8638 & -4.9256 \\
\hline \multicolumn{5}{|c|}{ Philippines } \\
\hline $\mathbf{Q}_{\mathrm{x}}{ }^{\mathrm{d}}$ & -1.7027 & -2.2053 & -4.0105 & -3.2116 \\
\hline $\mathbf{P x} / \mathbf{P w}$ & -1.3380 & -1.8139 & -3.9623 & -3.7427 \\
\hline Yw & -3.8837 & -2.9312 & -7.5241 & -5.4290 \\
\hline Gci & -3.2397 & -2.5257 & -7.9373 & -5.4891 \\
\hline
\end{tabular}

Table 1:

The DF/ADF Test for Unit Roots (Export)

Notes to table: All variables are in log.

Variables are as follows; total export index $\left(\mathrm{Q}_{\mathrm{x}}{ }^{\mathrm{d}}\right)$, relative price $(\mathrm{Px} / \mathrm{Pw})$, a weighted (by the share of exports) average of the trade partners GDP (Yw) and export composition index (Gci). Variables are as follows; total import index $\left(\mathrm{Q}_{\mathrm{m}}{ }^{\mathrm{d}}\right)$, relative price $(\mathrm{Pm} / \mathrm{Gp})$ and the real income $(\mathrm{Yb})$. ADF critical value for level is -3.5468 and ADF critical value for $1^{\text {st }}$ difference is -3.5514 .

All econometric computations have been carried out by Microfit 4.0 Version (see Pesaran \& Pesaran, (1997). In most of the cases, the intercept terms are included in the relevant DF and ADF equations. An augmentation of one seems sufficient to secure lack of autocorrelation of the error terms, however, in some cases, no augmentation was necessary. 
Table 2:

The DF/ADF Test for Unit Roots (Import)

\begin{tabular}{|c|c|c|c|c|}
\hline \multirow{2}{*}{$\begin{array}{l}\text { Variables } \\
\text { Country }\end{array}$} & \multicolumn{2}{|c|}{ Levels } & \multicolumn{2}{|c|}{$1^{\text {st }}$ Differences } \\
\hline & $\overline{\text { DF }}$ & ADF(1) & $\overline{D F}$ & ADF(1) \\
\hline \multicolumn{5}{|l|}{ Malaysia } \\
\hline $\mathbf{Q}_{\mathrm{m}}{ }^{\mathrm{d}}$ & -0.5268 & -0.5636 & -4.9922 & -4.9714 \\
\hline Pm/Gp & -1.3794 & -1.9296 & -4.2710 & -3.3686 \\
\hline $\mathbf{Y b}$ & -1.4940 & -2.0916 & -3.9630 & -3.9443 \\
\hline \multicolumn{5}{|l|}{ Indonesia } \\
\hline $\mathbf{Q}_{\mathrm{m}}{ }^{\mathrm{d}}$ & -1.7411 & -2.5599 & -3.1280 & -3.6050 \\
\hline $\mathbf{P m} / \mathbf{G p}$ & -3.1421 & -1.2691 & -9.1279 & -9.3000 \\
\hline $\mathbf{Y b}$ & -1.3572 & -1.8071 & -2.9900 & -3.6700 \\
\hline \multicolumn{5}{|l|}{ Thailand } \\
\hline $\mathbf{Q}_{\mathrm{m}}{ }^{\mathrm{d}}$ & -0.7757 & -1.5146 & -3.8270 & -3.9360 \\
\hline $\mathbf{P m} / \mathbf{G p}$ & -1.0663 & -1.8596 & -3.4775 & -3.2422 \\
\hline $\mathbf{Y b}$ & -1.6134 & -2.5190 & -3.8321 & -3.7318 \\
\hline \multicolumn{5}{|c|}{ Philippines } \\
\hline $\mathbf{Q}_{\mathrm{m}}{ }^{\mathrm{d}}$ & -0.8426 & -0.7381 & -8.4897 & -7.3153 \\
\hline Pm/Gp & -0.6882 & -0.7704 & -3.6138 & -3.8170 \\
\hline $\mathbf{Y b}$ & -1.4304 & -1.8214 & -3.8774 & -3.2588 \\
\hline
\end{tabular}

Notes to table: All variables are in $\log$

Variables are as follows; total import index $\left(\mathrm{Q}_{\mathrm{m}}{ }^{\mathrm{d}}\right)$, relative price $(\mathrm{Pm} / \mathrm{Gp})$ and the real income $(\mathrm{Yb})$. ADF critical value for level is -3.5468 and $\mathrm{ADF}$ critical value for $1^{\text {st }}$ difference is -3.5514 .

All econometric computations have been carried out by Microfit 4.0 Version (see Pesaran \& Pesaran, (1997). In most of the cases, the intercept terms are included in the relevant DF and ADF equations. An augmentation of one seems to sufficient to secure lack of autocorrelation in the error terms, however, in some cases, no augmentation was necessary.

\section{RESULTS}

\section{The OLS Residual-Based Test}

Table 3 reports the ADF residual based test results for cointegration for the export demand equations. Table 2, in Charemza and Deadman (1992), provides approximate critical values for the cointegration test for 30 observations with $\mathrm{m}=3$ at 5 percent level of significance which are -3.71 (lower bound) and -3.50 (upper bound). The null hypothesis of no cointegration is rejected if the value were below -3.71 ; and is not rejected if the value were above -3.50 . Values between -3.71 and
-3.50 lie in the inconclusive region. Based on the test statistics, the null hypothesis of no cointegration for the corresponding residual obtained from the long run export demand equation can be rejected at 5 percent level of significance (i.e. Malaysia and Indonesia). However, for Thailand's long run export demand equation, the corresponding residual obtained from the equation is in the 'inconclusive region' at 5 percent level of significance although the null of no cointegration can be rejected at 10 percent level of significance. For the case of the Philippines the null of no cointegration can also be rejected at 10 percent level of significance. 
For the import demand equation, the null hypothesis of no cointegration at 5 percent level of significance is rejected (i.e. Malaysia and Indonesia). For the Philippines, the null hypothesis of no cointegration at 10 percent level of significance is rejected. For Thailand, the corresponding residual obtained from the equation is slightly below the upper bound critical value. However, it is assumed that all variables are cointegrated as the standard tests are over-cautious in rejection of the null hypothesis of no cointegration. This emphasizes type 1 error whereas type 2 error, that is, failing to reject the null when it is false, is more important here. Consequently, we should be generous in interpreting the statistics. Accordingly, all variables involved in the equations are cointegrated, or, in short, the long run relationships among variables are not spurious. This is shown in Table 4.

The CRDW is used to see whether all the variables are cointegrated. Engle and Yoo (1987), provide a CRDW critical value for $\mathrm{n}=50$; the two variables case is 0.78 at 5 percent level of significance and 0.69 at 10 percent level of significance. By looking at the CRDW test statistics, the value of CRDW for Malaysia's export demand is 1.42 , which is larger than the 5 percent critical value and therefore the null of no cointegration is rejected.

Table 3:

ADF Residual-based Test for Cointegration The Long-run Export Equations

\begin{tabular}{lllllll}
\hline & \multicolumn{3}{c}{ Test Statistics } & \multicolumn{3}{c}{ Critical Values* } \\
\hline & DF & ADF(1) & \multicolumn{2}{c}{$\mathbf{5 \%}$} & \multicolumn{3}{c}{$\mathbf{1 0 \%}$} \\
\hline & & & U & L & U & L \\
\cline { 3 - 7 } Malaysia & -4.24 & -4.33 & -3.50 & -3.71 & -3.16 & -3.33 \\
Indonesia & -2.67 & -3.90 & -3.50 & -3.71 & -3.16 & -3.33 \\
Thailand & -3.58 & -3.64 & -3.50 & -3.71 & -3.16 & -3.33 \\
Philippines & -3.62 & -3.27 & -3.50 & -3.71 & -3.16 & -3.33 \\
\hline
\end{tabular}

Notes to table:

*The critical values are obtained from Charemza and Deadman (1992) with 30 numbers of observation and $\mathrm{m}=3$. One also can refer to other sources of critical value tables i.e. MacKinnon (1991), Engle-Granger (1987, Tables II and III), Engle and Yoo (1987).

Table 4:

ADF Residual-based Test for Cointegration The Long-run Import Equations

\begin{tabular}{lllllll}
\hline & \multicolumn{2}{c}{ Test Statistics } & \multicolumn{4}{c}{ Critical Values* } \\
\hline & DF & ADF(1) & \multicolumn{2}{c}{$\mathbf{5 \%}$} & $\mathbf{1 0 \%}$ \\
\cline { 3 - 7 } & & & U & L & U & L \\
\hline Malaysia & -2.99 & -3.69 & -3.15 & -3.31 & -2.80 & -2.96 \\
Indonesia & -2.13 & -3.29 & -3.15 & -3.31 & -2.80 & -2.96 \\
Thailand & -1.79 & -2.34 & -3.15 & -3.31 & -2.80 & -2.96 \\
Philippines & -1.89 & -2.80 & -3.15 & -3.31 & -2.80 & -2.96 \\
\hline
\end{tabular}

Notes to table;

*The critical values are obtained from Charemza and Deadman (1992) with 30 numbers of observation and $\mathrm{m}=2$. One also can refer to other sources of critical value tables i.e. MacKinnon (1991), Engle-Granger (1987, Tables II and III), Engle and Yoo (1987). 


\section{The DOLS}

Table 5 shows the dynamic OLS parameter estimates of the long-run export demand with all variables in levels, along with their approximate asymptotic standard errors for all countries. Based on the results obtained, for most cases both the long run income and price elasticities have correct signs as anticipated. The long run income elasticities vary from 0.15 (Philippines) to 1.37 (Thailand). In all cases, they are significant. The long-run price elasticities vary from -0.26 (Indonesia) to -2.41 (Thailand). As the export compo- sition index is only significant for Malaysia, it is dropped for the other three countries.

The price elasticities in the import demand equations are correctly signed and are significant. The long run price elasticity of import demand vary from -0.27 (Philippines) to -1.50 (Thailand). The income variable was also correctly signed and significant for all cases. The long run income elasticities vary from 0.35 (Philippines) to 0.90 (Malaysia). Table 6 reports the results for import demand equations that show the correct signs for both income and price elasticities.

Table 5:

The DOLS Export Demand Equations (long run)

\begin{tabular}{llllll}
\hline Country & Px/Pw & Yw & Gci & ser & $\mathbf{R}^{\mathbf{2}}$ \\
\hline Malaysia & -0.35 & 0.21 & 1.69 & 0.05 & 0.99 \\
& $(0.0646)$ & $(0.0621)$ & $(0.1715)$ & & \\
Indonesia & -0.26 & 0.53 & - & 0.12 & 0.96 \\
& $(0.1076)$ & $(0.0488)$ & & & \\
Thailand & -2.41 & 1.37 & - & 0.12 & 0.98 \\
& $(0.3911)$ & $(0.0723)$ & & & 0.12 \\
Philippines & -0.32 & 0.15 & - & & \\
& $(0.1273)$ & $(0.0656)$ & & & \\
\hline
\end{tabular}

Notes: value in parenthesis is standard errors

Table 6:

The DOLS Import Demand Equations (long run)

\begin{tabular}{lllll}
\hline Country & Pm/Gp & Yb & Ser & $\mathbf{R}^{2}$ \\
\hline Malaysia & -1.24 & 0.90 & 0.24 & 0.93 \\
& $(0.858)$ & $(0.1169)$ & & \\
Indonesia & -0.41 & 0.46 & 0.14 & 0.96 \\
& $(0.1974)$ & $(0.0996)$ & & \\
Thailand & -1.50 & 0.70 & 0.09 & 0.98 \\
& $(0.1505)$ & $(0.0215)$ & & \\
Philippines & -0.27 & 0.35 & 0.15 & 0.88 \\
& $(0.0898)$ & $(0.069)$ & & \\
\hline
\end{tabular}

Notes: value in parenthesis is standard errors 
The Johansen Maximum Likelihood Approach By applying the Johansen Maximum Likelihood approach (see Johansen, (1991), cointegration are found for all countries. Information from the unrestricted VAR model is used to determine the order of the VAR. The Schwarz Bayesian Criterion (SBC), and the Akaike Information Criterion (AIC) were used to determine the optimal lag length. The log-likelihood ratio statistics were then used for testing zero restrictions on the coefficients of a subset of deterministic/exogenous variable; the presence of an intercept could not be rejected.
The results of the Johansen-Juselius cointegration tests for both exports and imports are shown in Tables 7 and 8. The trace statistics and the eigenvalue (maximum) tests show that there exists only one cointegrating relationship. The Johansen Likelihood ratio statistics were used to determine the number of cointegrating vectors, $r$. Both the maximal eigenvalue and the trace tests were used, testing the null hypothesis of $r$ cointegrating vectors for $r=0$, followed by $r \leq 1$ and $\mathrm{r} \leq 2$.

Table 7:

The Johansen Maximum Likelihood Cointegration Test - Exports

Malaysia: Cointegration with Unrestricted Intercepts and No Trends in the VAR $(k=2)$

\begin{tabular}{lcrcccr}
\hline Eigenvalue & $\lambda_{\max }$ & $\lambda_{\text {Trace }}$ & $\mathbf{H}_{\mathbf{0}}=\mathbf{r}$ & $\mathbf{H}_{\mathbf{A}}=\mathbf{P}-\mathbf{r}$ & \multicolumn{2}{c}{ Critical Value } \\
\hline & & & & & 95\% L- max & 95\% trace \\
\hline 0.70729 & 39.31401 & 55.1817 & 0 & 1 & 27.42 & 48.80 \\
0.26291 & 9.7613 & 15.8678 & 1 & 2 & 21.12 & 31.54 \\
0.15325 & 5.3231 & 6.1064 & 2 & 3 & 14.88 & 17.86 \\
0.0241842 & 0.78339 & 0.78339 & 3 & 4 & 8.07 & 8.07 \\
\hline
\end{tabular}

Indonesia: Cointegration with Unrestricted Intercepts and No Trends in the VAR $(k=1)$

\begin{tabular}{lcccccr}
\hline Eigenvalue & $\lambda_{\max }$ & $\lambda_{\text {Trace }}$ & $\mathbf{H}_{\mathbf{0}}=\mathbf{r}$ & $\mathbf{H}_{\mathbf{A}}=\mathbf{P}-\mathbf{r}$ & \multicolumn{2}{c}{ Critical Value } \\
\hline & & & & & $\mathbf{9 5 \%}$ L-max & 95\% trace \\
\hline 0.60813 & 29.9783 & 53.9768 & 0 & 1 & 27.42 & 48.80 \\
0.43334 & 18.1758 & 23.9985 & 1 & 2 & 21.12 & 31.54 \\
0.16377 & 5.7233 & 5.8228 & 2 & 3 & 14.88 & 17.86 \\
0.031024 & 0.099431 & 0.099431 & 3 & 4 & 8.07 & 8.07 \\
\hline
\end{tabular}

Thailand: Cointegration with Unrestricted Intercepts and No Trends in the VAR $(k=2)$

\begin{tabular}{lrrllrr}
\hline Eigenvalue & $\lambda_{\max }$ & $\lambda_{\text {Trace }}$ & $\mathbf{H}_{\mathbf{0}}=\mathbf{r} \mathbf{H}_{\mathbf{A}}=\mathbf{P}-\mathbf{r}$ & \multicolumn{2}{c}{ Critical Value } \\
\hline 0.65517 & & & & & $\mathbf{9 5 \%} \mathbf{L}-\mathbf{m a x}$ & $\mathbf{9 5 \%}$ trace \\
0.17991 & 33.0058 & 39.6372 & 0 & 1 & 21.12 & 31.54 \\
0.015457 & 0.1485 & 6.6315 & 1 & 2 & 14.88 & 17.86 \\
\hline
\end{tabular}

Philippines: Cointegration with Unrestricted Intercepts and No Trends in the VAR $(k=1)$

\begin{tabular}{lrrrcrr}
\hline Eigenvalue & $\lambda_{\max }$ & $\lambda_{\text {Trace }}$ & $\mathbf{H}_{\mathbf{0}}=\mathbf{r}$ & $\mathbf{H}_{\mathbf{A}}=\mathbf{P}-\mathbf{r}$ & \multicolumn{2}{c}{ Critical Value } \\
\hline & & & & & $\mathbf{9 5 \%}$ L-max & 95\% trace \\
\hline 0.51959 & 21.2602 & 35.7503 & 0 & 1 & 27.42 & 45.70 \\
0.25767 & 8.6410 & 14.4902 & 1 & 2 & 21.12 & 28.78 \\
0.16226 & 5.1345 & 5.8492 & 2 & 3 & 14.88 & 15.75 \\
0.024346 & 0.71476 & 0.71476 & 3 & 4 & 8.07 & 8.07 \\
\hline
\end{tabular}

Notes: critical values for $\lambda_{\max }$ and $\lambda_{\text {Trace }}$ are from Microfit. 
Table 8:

The Johansen Maximum Likelihood Cointegration Test - Imports

Malaysia: Cointegration with Unrestricted Intercepts and No Trends in the VAR $(k=2)$

\begin{tabular}{lrrrrrr}
\hline Eigenvalue & $\lambda_{\max }$ & $\lambda_{\text {Trace }}$ & $\mathbf{H}_{\mathbf{0}}=\mathbf{r}$ & $\mathbf{H}_{\mathbf{A}}=\mathbf{P}-\mathbf{r}$ & \multicolumn{2}{c}{ Critical Value } \\
\hline 0.51084 & & & & & 90\% L-max & 90\% trace \\
0.15299 & 22.17 & 27.83 & 0 & 1 & 19.02 & 28.78 \\
0.016594 & 5.14 & 5.67 & 1 & 2 & 12.98 & 15.75 \\
\hline
\end{tabular}

Indonesia: Cointegration with Unrestricted Intercepts and No Trends in the VAR $(k=2)$

\begin{tabular}{lrrccrr}
\hline Eigenvalue & $\lambda_{\max }$ & $\lambda_{\text {Trace }}$ & $\mathbf{H}_{\mathbf{0}}=\mathbf{r}$ & $\mathbf{H}_{\mathrm{A}}=\mathbf{P}-\mathbf{r}$ & \multicolumn{2}{c}{ Critical Value } \\
\hline 0.48118 & & & & & $\mathbf{9 0 \%}$ L-max & 90\% trace \\
0.28714 & 17.72 & 27.99 & 0 & 1 & 19.02 & 28.78 \\
0.041468 & 9.14 & 10.28 & 1 & 2 & 12.99 & 15.75 \\
\hline
\end{tabular}

Thailand: Cointegration with Unrestricted Intercepts and No Trends in the VAR $(k=2)$

\begin{tabular}{lrrccrr}
\hline Eigenvalue & $\lambda_{\max }$ & $\lambda_{\text {Trace }}$ & $\mathbf{H}_{\mathbf{0}}=\mathbf{r}$ & $\mathbf{H}_{\mathbf{A}}=\mathbf{P}-\mathbf{r}$ & \multicolumn{2}{c}{ Critical Value } \\
\hline 0.62767 & & & & & $\mathbf{9 0 \%}$ L-max & $\mathbf{9 0 \%}$ trace \\
0.06386 & 29.64 & 31.63 & 0 & 1 & 19.02 & 28.78 \\
$0.3434 \mathrm{E}-3$ & 1.98 & 1.99 & 1 & 2 & 12.98 & 15.75 \\
& 0.0103 & 0.010304 & 2 & 3 & 6.50 & 6.5 \\
\hline
\end{tabular}

Philippines: Cointegration with Unrestricted Intercept and No Trends in the VAR $(k=2)$

\begin{tabular}{lrrrcrr}
\hline Eigenvalue & $\lambda_{\max }$ & $\lambda_{\text {Trace }}$ & $\mathbf{H}_{\mathbf{0}}=\mathbf{r}$ & $\mathbf{H}_{\mathbf{A}}=\mathbf{P}-\mathbf{r}$ & \multicolumn{2}{c}{ Critical Value } \\
\hline 0.46026 & & & & & $\mathbf{9 0 \%}$ L-max & $\mathbf{9 0 \%}$ trace \\
0.20704 & 18.50 & 28.30 & 0 & 1 & 22.26 & 36.28 \\
0.090358 & 6.96 & 9.80 & 1 & 2 & 16.28 & 21.23 \\
& 2.84 & 2.84 & 2 & 3 & 9.75 & 9.75 \\
\hline
\end{tabular}

Notes: critical values for $\lambda_{\max }$ and $\lambda_{\text {Trace }}$ are from Microfit.

For the export demand equation, in most cases the maximal eigenvalue test (1-max test) indicates that the null hypothesis of zero cointegrating vectors is rejected at 95 percent critical value except for the case of the Philippines. (see Pesaran \& Pesaran, 1997). The trace test confirms that there is only one cointegrating relationship among the variables for all countries except for the case of the Philippines. However, based on the choice of the number of cointegrating relations using model selection criteria, both the Akaike Information Criteria (AIC) and the Hannan-Quinn Criteria (HQC) select one cointegrating relationship.
For the import demand equation, the maximal eigenvalue test and the trace test, indicate that the null hypothesis of zero cointegrating vectors is rejected at 90 percent critical value except for the case of the Philippines and Indonesia. Nevertheless, based on the choice of the number of cointegrating relations using model selection criteria, the Schwarz Bayesian Criteria (SBC) selects one cointegrating relationship for both the Philippines and Indonesia. The estimation of the normalized cointegrating vector then is obtained as the existence of the relationship among the variables is accepted. This is shown in Table 9. 
For most of the cases, the price and income elasticities of export demand are all correctly signed. In the Malaysian case, the long run price and income elasticities are -0.35 and 0.20 respectively. They are both statistically significant. The export composition index also has the predicted sign and is also significant with the value of 1.71. In the Indonesian case, the long run price and income elasticities are -0.3 and 0.67 , respectively and both are statistically significant. For the case of Thailand, the price and income elasticities have the predicted sign and both are significant. The long run price elasticity is -2.69 and the long run income elasticity is 1.43 . For the Philippines, the long run price elasticity is -0.25 and the long run income elasticity is 0.17 . They are both correctly signed and significant. A restriction is imposed on the export composition index (GCI) that $44=$ 0 , obviously for the Malaysian case, the $\mathrm{c}^{2}$ is statistically significant, and therefore the null hypothesis of no relationship between the export demand and the export composition index is rejected. For the import demand equations, in all cases the price and income elasticities are all correctly signed and are significant (see table 9). These results suggest that both relative price and real income are crucial in determining import demand.

Table 9:

Results from the DOLS and the Johansen VAR Approaches

\begin{tabular}{|c|c|c|c|c|c|c|}
\hline \multirow[t]{2}{*}{ Country } & \multirow[t]{2}{*}{ Variables } & \multicolumn{3}{|c|}{ Exports Variables } & \multicolumn{2}{|l|}{ Imports } \\
\hline & & E-G & Johansen & & E-G & Johansen \\
\hline \multicolumn{7}{|l|}{ Malaysia } \\
\hline & $(\mathbf{p x} / \mathbf{p w})$ & -0.35 & -0.35 & $(\mathbf{p m} / \mathbf{g p})$ & -1.24 & -2.19 \\
\hline & & $(0.0646)$ & $(0.056)$ & & $(0.858)$ & $(0.734)$ \\
\hline & Yw & 0.21 & 0.20 & $\mathbf{Y b}$ & 0.90 & 1.02 \\
\hline & & $(0.0621)$ & $(0.053)$ & & $(0.1169)$ & $(0.096)$ \\
\hline & Gci & 1.69 & 1.70 & & & \\
\hline & & $(0.1715)$ & $(0.1473)$ & & & \\
\hline \multicolumn{7}{|l|}{ Indonesia } \\
\hline & $(\mathbf{p x} / \mathbf{p w})$ & -0.26 & -0.30 & $(\mathbf{p m} / \mathrm{gp})$ & -0.41 & -0.51 \\
\hline & & $(0.1076)$ & $(0.104)$ & & $(0.1974)$ & $(0.213)$ \\
\hline & Yw & 0.53 & 0.67 & $\mathbf{Y b}$ & 0.46 & 0.42 \\
\hline & & $(0.0488)$ & $(0.051)$ & & $(0.0996)$ & $(0.121)$ \\
\hline \multicolumn{7}{|l|}{ Thailand } \\
\hline & $(\mathbf{p x} / \mathbf{p w})$ & -2.41 & -2.69 & $(\mathbf{p m} / \mathbf{g p})$ & -1.50 & -1.75 \\
\hline & & $(0.3911)$ & $(0.510)$ & & $(0.1505)$ & $(0.196)$ \\
\hline & Yw & 1.37 & 1.43 & $\mathbf{Y b}$ & 0.70 & 0.74 \\
\hline & & $(0.0723)$ & $(0.096)$ & & $(0.0215)$ & $(0.026)$ \\
\hline \multicolumn{7}{|l|}{ Philippines } \\
\hline & $(\mathbf{p x} / \mathbf{p w})$ & -0.32 & -0.25 & $(\mathbf{p m} / \mathrm{gp})$ & -0.27 & -1.34 \\
\hline & & $(0.1273)$ & $(0.186)$ & & $(0.0898)$ & $(0.741)$ \\
\hline & Yw & 0.15 & 0.17 & $\mathbf{Y b}$ & 0.35 & 0.99 \\
\hline & & $(0.0656)$ & $(0.061)$ & & $(0.069)$ & $(0.759)$ \\
\hline
\end{tabular}

Notes: values in parenthesis are standard errors 


\section{CONCLUSION AND POLICY IMPLICATIONS}

This paper provides estimation of price and income elasticities of export and import demand using both dynamic OLS and Johansen Maximum Likelihood approaches. The cointegration analysis is employed to ensure that regressions are not spurious. Results show that both the price and income elasticity of exports and imports demand, have correct signs as anticipated and significant. The inelasticity of export demand for most countries is expected, as the bulk of these countries exports are in the form of strategic raw materials used for industrial purposes.

Different estimates of the price elasticities of export demand function leads to different implications for trade policies. As argued by Athukorala and Riedel (1990), if price elasticities really were low, then standard trade theory would suggest that policy-makers in developing countries should have advocated export taxes in place for export promotion. However, liberalization of trade can lead to a massive boost to export growth rates in developing countries; that is, the Turkish experiences in the 1980s.

There are also implications for (real) exchange rate of cost competitiveness policy. Suppose that the price elasticities of demand are indeed low, one would expect a policy of allowing a real depreciation to generate a rather small expansion of the varieties produced in ASEAN countries. But lower wage costs will attract producers of new varieties to the ASEAN countries, thus boosting supply and demand at the same time. Therefore a real depreciation policy should not be seen as a way of cheapening supply, which will, of itself attract purchasers.

Based on the results obtained, one can observe that foreign income is a significant variable in the export demand equation, suggesting that foreign disturbance in the form of fluctuation in foreign economic activities is likely to be transmitted to those countries. The Marshall-Lerner conditions are met for Malaysia and Thailand as the sum of their price elasticity of export and import demand are greater than unity (both DOLS and Johansen Maximum Likelihood approaches), suggesting that appreciations (depreciations) in exchange rates can worsen (improve) the current account in a period of one year. For the case of the Philippines and Indonesia, however, the sum of the price elasticities of exports and imports are less than unity. This can be explained by the Jcurve, in which export and import demands tend to be relatively inelastic due to the existence of lags. The J-curve also shows that currency depreciation will first worsen the trade balance before it improves and it takes time to affect the current account. As mentioned earlier, the exchange rate policy is always accompanied by other macroeconomic policies, as it is difficult to assess the effects of one policy without controlling for the others.

\section{REFERENCES}

Aspe, P., \& Giavazzi, F. (1982). The short run behaviour of prices and output in the exportable sector: The case of German machinery. Journal of International Economics, 12, 83-93.

Athukorala, P., \& Riedel, J. (1996). Modelling NIE exports: Aggregation, Qualitative, Restrictive Restrictions and choice of econometric methodology. Journal of Development Studies, 33, 81-98.

Baffes, J., Elbadawi, I. A., \& O’ Connell, S. A. (1999). Single-equation estimation of the equilibrium real exchange rate in Hinkle, Lawrence E., \& Peter, J. Montiel: Exchange rate misalignment: Concepts and measurement for developing countries. Oxford: Oxford University Press.

Banerjee, A., Galbraith, J. W., \& Hendry, D. (1993). Cointegration and the econometric analysis of non-stationary data. Oxford: Oxford University Press.

Bond, M. (1985). Export demand and supply for groups of non-oil developing countries. IMF Staff Papers, 32, 56-77. 
Cline, W. R. (1984). International debt systemic risk and policy response. Mass: Institute for International Economics. MIT Press: Cambridge.

Charemza, W. W., \& Deadman, D. F. (1992). New directions in econometric practice: General to specific modelling, cointegration and vector autoregression. Aldershot: Edward Elgar.

Cuthbertson, K., Hall, S. G., \& Taylor, M. P. (1992). Applied econometric techniques. New York: Phillip Allan.

Engle, R. F., \& Yoo, B. S. (1987). Forecasting and testing in cointegrated systems. Journal of Econometrics, 35, 143-59.

Engle, R. F., \& Granger, C. W. J. (1987). Cointegration and error correction: Representation, estimation, and testing. Econometrica, 55, 251-276.

Goldstein, M., \& Khan, M. S. (1978). The supply and demand for exports: A simultaneous approach. Review of Economics and Statistics, 60, 275-86.

(1982). Effects of slow down in industrial countries a growth in non-oil developing countries. IMF Occasional Paper, 12.

Houthhakker, H. S., \& Stephen, M. (1969). Income and price elasiticities in world trade. The Review of Economics and Statistics, 51, 111-125.

Johansen, S. (1991). Estimation and hypothesis testing of cointegration vectors in Gaussian vector autogressive model. Econometrica, 59, 1551-1580.

Khan, M. S. (1974). Import and exports demand in developing countries. IMF Staff Paper. 21, 169-210.
Marquez, J., \& McNeilly, C. (1988). Income and price elasticities for exports of developing countries. Review of Economics and Statistics, 70, 306-314.

MacKinnon, J. G. (1991). Critical values for integration tests in Long Run Economic Relationships: Reading in Co-Integration. R. F. Engle \& C. W. J. Granger (Eds.) Oxford: Oxford University Press.

Muscatelli, V. A. (1994). Demand and Supply factors in the determination of NIE Exports, a reply. Economic Journal, 104, 14151417.

Muscatelli, V. A., Stevensen, A. A., \& Montagna, C. (1995a) An analysis of the disaggregated manufacturing exports of the Asian NIEs to EEC, USA, and Japan. Applied Economics, 27, 17-24.

Muscatelli, V. A. (1995b). Modelling aggregate manufactured exports for some Asian newly industrialized economies. Review of Economics and Statistics, 77, 147155.

Mohamad Haji Alias, \& Tang Tuck Cheong (2000). Aggregate imports and expenditure components in Malaysia: A cointegration and error correction analysis. Presented in Monash University Malaysia International Symposium on Malaysia Business in the New Era, 23$24 \mathrm{Feb}, 2000$.

O’Neill, H. M., \& Ross, W. (1991). Exchange rates and South Korea exports to OECD countries. Applied Economics, 23, 1227-1236.

Pesaran, B. H., \& Pesaran, B. (1997). Microfit: An interactive econometric software package (user manual). Oxford: Oxford University Press.

Philip, P. C. B., \& Loretan, M. (1991). Estimating long-run economic equilibria. Review of Economic Studies, 58, 407-436. 
Riedel, J. (1984). Trade as the engine of growth in developing countries, revisited. Economic Journal, 94, 56-73.

(1988). The demand for LDC exports of manufactures: Estimates from Hong Kong. The Economic Journal, 98, 138148.

(1989). The demand for LDC exports of manufactures: Estimates from Hong Kong: A rejoinder. The Economic Journal, 99, 467-470.

Saikkonen, P. (1991). Asymptotically efficient estimation of co-integration regressions. Econometric Theory, 7, 1-21.

Tang Tuck Cheong (2003). Are imports and exports of the five ASEAN economies cointegrated? An empirical Study. International Journal of Management, 20 (1), 88-91

\section{APPENDIX}

The Computation of the Variables of Export and Import Demand.

All data required for the estimation were gathered and verified from various issues of the International Financial Statistics, and the World Tables of the World Bank. The trade share statistics used to compute the foreign variable were taken from the United Nations Yearbook of International Trade Statistics. The data is defined as below, and they are in the indexes of the base year 1990. All data is expressed in US dollars.

Qx = Index of the volume of exports $(1990=100)$ calculated by using the following formula

Qx $=$ EXUS/Px

Where EXUS and Px are exports in US dollars and export price indexi $n$ US dollar term respectively.
$\mathbf{Q m}=$ Index of the volume of imports $(1990=100)$ calculated by using the following formula;

$\mathrm{Qm}=\mathrm{IMUS} / \mathrm{Pm}$

Where IMUS and PM are imports in US dollars and import price index in US dollar term respectively.

Pw = index of the world export price $(1990=100)$ calculated by using the method of Houthakker and Magee (1969) and Goldstein and Khan (1978).

Yw = the trade-weighted 'world' real income, calculated as a weighted average of real incomes of five major export partners of each country. Expressed as an index $(1990=100)$ facing the country (see Houthakker and Magee, 1969).

GCI $=$ The export composition index

The index is constructed as follows. The exports good is divided into four groups $\left(\mathrm{C}_{1}, \ldots . \mathrm{C}_{4}\right)$.

$\mathrm{C}_{1}=$ Total exports of agricultural products and crude material

$\mathrm{C}_{2}=$ Total exports of traditional manufacturing sectors

$\mathrm{C}_{3}=$ Total exports of scale intensive sectors

$\mathrm{C}_{4}=$ Total exports of specialised supply and science based sectors

Following Muscatelli et al. (1995b) the export composition indexes is constructed using the formula below. The index GCI lies over interval $(0,1)$. The weights chosen are $a_{1}=0, a_{2}=0.33, a_{3}=0.67$, $a_{4}=1$, over the interval $(0,1)$.

$$
G C I_{t}=\frac{\sum_{i=1}^{4} a c_{i i t}}{\sum_{i=1}^{4} c_{i t}}
$$

